University of Windsor

Scholarship at UWindsor

\title{
Internal stakeholder views of a market orientation strategy: Implications for implementation
}

Francine K. Schlosser

Odette School of Business, University of Windsor

Rod McNaughton

Follow this and additional works at: https://scholar.uwindsor.ca/odettepub

Part of the Business Commons

\section{Recommended Citation}

Schlosser, Francine K. and McNaughton, Rod. (2007). Internal stakeholder views of a market orientation strategy: Implications for implementation. Journal of Strategic Marketing, 15 (4), 307-325.

https://scholar.uwindsor.ca/odettepub/115

This Article is brought to you for free and open access by the Odette School of Business at Scholarship at UWindsor. It has been accepted for inclusion in Odette School of Business Publications by an authorized administrator of Scholarship at UWindsor. For more information, please contact scholarship@uwindsor.ca. 
Internal Stakeholder Views of a Market Orientation Strategy: Implications for Implementation

Citation: Schlosser, Francine K. and McNaughton Rod B., Understanding Stakeholder Views of a Market Orientation Strategy, Journal of Strategic Marketing, 15(4), 307-325, 2007, September.

Correspondence to:

Francine K. Schlosser

Management and Labour Studies

University of Windsor

Windsor, ON

N9B 3P4

Email: fschloss@uwindsor.ca

Phone: (519) 253-3000 ext. 3107 
Internal Stakeholder Views of a Market Orientation Strategy: Implications for Implementation

The market orientation literature focuses upon external stakeholders as the content or target of a market orientation strategy. This is problematic for understanding the successful implementation of a market orientation strategy because internal stakeholders provide the link between strategy-makers and external stakeholder targets. Anchored in market orientation, dynamic capabilities, and stakeholder research, the study describes how internal stakeholders in a market orientation process can impede or encourage the achievement of market-oriented objectives by a market-oriented company. Focus groups were conducted with both management and non-management employees of a large market-oriented financial services organisation that recently introduced a market-oriented agency call program. The extent to which the company is market-oriented was determined through preliminary interviews with senior executives and distributor/customers. Results highlight 1) program antecedents related to employee disposition and control, 2) potentially competing program objectives (relationship and knowledge acquisition), 3) issues of role conflict, time constraints, and 3) the need to confirm program value through feedback solicited from other stakeholders.

Key Words: Market Orientation, Internal Stakeholder, Stakeholder, Employee Attitudes, Strategy, Services Marketing 


\section{Introduction}

A successful market-oriented strategy requires the input of multiple stakeholders both internal and external to the organisation. This strategy involves the acquisition and dissemination of information and coordination of strategic response (Kohli and Jaworski, 1990) and is linked to many key organisational performance indicators (e.g., Narver and Slater, 1990). Market orientation has garnered much attention from researchers because it clearly contributes to a firm's competitive advantage, through its demonstrated relationships with financial performance (e.g., Greenley, 1995; Slater and Narver, 1994) and innovation (e.g., Atuahene-Gima, 1996; Han et al., 1998). Parties with a stake in this strategy include 1) internal stakeholders, such as executives who set the strategy and employees who implement it, and 2) external stakeholders, such as businesses who partner in strategic delivery and customers who are targeted by a market orientation strategy.

Although it is important for companies to consider all stakeholders involved in the marketing strategy process (Greenley and Foxall, 1998), the market orientation literature continues to focus upon external stakeholders. This external focus has limited multiple stakeholder approaches to an appreciation of customer and competitor targets in a market orientation strategy. For example, despite concerns that competitor and customer orientations may not always be compatible (Deshpande et al., 1993), Day and Wensley (1988) suggested that a firm can become myopic if it concentrates only on adaptive/reactive customer-oriented strategies.

Seminal measures of the market orientation construct include questions regarding the free flow of information between departments and functions, but empirical use of the 
measures is limited to senior executives (e.g., Kennedy et al., 2002) or sales/marketing employees (e.g., Langerak, 2001). Piercy et al. (2002) examined the connection between the job attitudes held by shop floor employees and their managers' views of organizational market orientation. Building on this, there is a need to examine the attitudes and accountability of operational employees for their own market-oriented actions. We seek to remedy this gap in the market orientation literature by obtaining and analyzing the views of internal employee stakeholders at varying levels and positions throughout the organisation. It is important to consider the market oriented behaviours of all employees because access to market information increases employee understanding of the "big picture", and creates opportunities for a more co-ordinated strategic response.

When implementing market orientation strategies, organisations use tactics such as systems that manage customer contacts and relationships (CRM). Debate on the continued failure of CRM systems focuses upon the need for management to build relationships with both internal (employees) and external stakeholders (customers) (e.g., Croteau and Li, 2003; Earley, 2002; Tehrani, 2002). Employee stakeholders play an important role in the recognition and dissemination of market information to relevant decision-makers throughout the organisation. However, not all employees understand the importance of knowledge transfer up the hierarchy. This lack of understanding may be role-related and arise out of an ignorance of the importance (or a different understanding) of management expectations. Alternatively, there may be interpersonal issues where employees who believe that they have been treated unfairly by the company may not be willing to share valuable market information (Harris, 2002). 
Through interviews and focus groups, the research reported in this paper investigates how employee stakeholders perceive the market orientation process used to get and respond to information. As strategic partners, employees make qualitative judgements regarding the appropriateness of a market-oriented strategy and its implementation. Perceptions of its value may be shaped by their own goals vis-à-vis the firm. Additionally, these perceptions will influence the development of interpersonal relationships that support strategic initiatives.

Understanding this issue requires a depth of analysis achieved through qualitative research methods. Thus, this paper provides a qualitative empirical assessment of the thematic differences and commonalities among internal (employee) stakeholders. First this study is anchored in market orientation, dynamic capabilities and stakeholder research. Then, a market-oriented strategy is profiled through interviews with 12 executive strategy setters and 10 distributors. Building upon this base, the results of focus groups are reported. Focus groups include 30 management and non-management employees with responsibility for implementing the market-oriented strategy of the same organisation. Employee conceptions of program value and expectations of behaviours and priorities reveal areas that assist or impede the introduction of market-oriented programs. Although the market orientation area has been well-researched, the research employs a case-based approach in order to understand the less understood individual and interpersonal contexts associated with strategic implementation. 


\section{Developing Dynamic Capabilities through a Market Orientation Strategy}

A market orientation involves the transfer of knowledge through interpersonal coordination and interaction. The market orientation of a firm builds upon three dimensions: the organisation-wide acquisition, dissemination, and co-ordination of market intelligence (Jaworski and Kohli, 1993). For example, a firm is market-oriented when it has routines in place such as: talking with or surveying those who can influence end-users' purchases (e.g., retailers, distributors), disseminating data on customer satisfaction at all levels in a business unit on a regular basis, and efficient strategies in place to respond to changes in the market, such as changes in competitors' price or customer needs (Kohli et al., 1993). Empirical research links market orientation to both financial and market indicators of firm performance (e.g., Farrell, 2000) .

A market orientation fosters an awareness of the external market, which requires response at appropriate levels and functions of the firm. Therefore, the value of market orientation lies in its ability to prompt reconfiguration of resources, specifically through the processing, use and value of market information in the: a) information, or the recognition by employee of the information's value to the firm, b) resulting information sharing and inter-functional coordination and finally, c) employee/employer's use of the information to shape reactions.

A dynamic capabilities framework explains this link between firm processes and value creation. A dynamic capability is reflected in systematic learning processes within the organisation (Winter, 2000) and represents the ability to renew competencies in response to changing market conditions (Eisenhardt and Martin, 2000; Teece et al., 
1997). The value of market orientation as a dynamic capability rests in the combined effect of customer orientation and information sharing. Day (1994) discussed the importance of developing market-sensing and customer-linking capabilities to create an external or market-driven focus throughout the organisation. A market sensing capability "determines how well the organisation is equipped to continuously sense changes in its market and to anticipate the responses to marketing actions" and a customer linking capability "comprises the skills, abilities, and processes needed to achieve collaborative customer relationships" (Day, 1994, p. 49).

A market orientation is supported by underlying interwoven and synchronized layers of values, norms and behaviours throughout the organisation (Homburg and Pflesser, 2000). These layers are reflected through the individual behaviours and interpersonal processes of employees at all levels. In the strategy literature, an individual behaviourally-based view of capabilities is proposed by Dobni and Luffman (2000, p. 911): "Capabilities emanate from individual employees and include complex bundles of skills and accumulated knowledge that enable firms to coordinate activities and make use of their assets." It is imperative that firms unlock these dynamic capabilities in order to develop more sustainable competitive advantage. An adaptive and flexible market oriented strategy will avoid the development of core rigidities (Leonard-Barton, 1992) as opposed to truly dynamic capabilities.

Market-oriented capabilities arise out of the unique interpersonal relationships and sources of information cultivated by market-oriented employees. Clearly, a marketoriented direction must seek to do more than develop relationships with stakeholders. The relationship is a process that facilitates the quest for market information. Organisations 
foster market orientation informally when individuals are encouraged to exchange resources. Relationships involve reciprocity (Foa and Foa, 1974; Roloff and Campion, 1985), such that in this case, individuals are more likely to share market information with someone who has shared information with them. In this way, the reciprocity inherent in interpersonal exchanges becomes a compounded source of dynamic value.

\section{Internal Stakeholders in a Market Orientation Strategy}

A market orientation strategy both targets and is influenced by internal stakeholders. A seminal definition of stakeholder is provided by Freeman (1984, p. vi.), who defined a stakeholder as "any group or individual who can affect, or is affected by, the achievement of a corporation's purpose".

Organisations with a market-oriented strategy influence the behaviours and attitudes of internal stakeholders, such as employees (Celuch et al., 2000; Langerak, 2001). Internal stakeholders also influence the market orientation of an organisation (Harris and Ogbonna, 2001; Harris and Piercy, 1999; Hurley, 2002; Kennedy et al., 2002; Noble and Mokwa, 1999). Although employees may influence the organisation through managerial decision makers (Frooman, 1999), they can more directly influence organisational performance through behaviours and attitudes and interaction (for example, by developing relationships with customers or channel partners). Not all employees may see it as their responsibility to influence strategic decision makers.

This type of attitude might influence the ability of the organisation to get crucial market information through relationship development. Unlike a marketing orientation, a market orientation orients all employees toward the market (Kotler and Armstrong, 
1996), involving decision making and organisational learning throughout the company and the understanding of changes in the external environment (Uncles, 2000). It involves business processes, which require decision-making and an understanding of both internal capabilities and changes in the external marketing environment. Stakeholder relationship management across the organisation enhances the ability of marketing personnel to manage customer relationships.

Employees who are not in marketing but still experience frequent customer contact may differ in their management of these relationships and their conceptions of market-oriented behaviours. Senior management may not see the need for market orientation of employees who deal infrequently with customers. Employees themselves may perceive their responsibilities differently. Therefore, it is important to understand each stakeholder's perception of relationship and knowledge management processes. This includes an understanding of stakeholder perceptions of the market orientation process used to get and respond to information and subsequent judgements of the appropriateness and value of the strategy in reaching each stakeholder's goals.

Frooman (1999) described multi-actor relationships, involving triads where stakeholders act through allies to influence firms. He proposed that weaker stakeholders can strengthen their influence by exploiting the relationship between the organisation and more powerful stakeholders. In general, stakeholder researchers consider relationship development with the organisational entity (e.g., Mitchell et al., 1997), yet relationships with non-living entities are weaker than relationships with people. Senior management who make corporate decisions are often removed from front-line customer contact. In order to strengthen the relatively weak relationship between an entity and its customers, 
management must develop individual relationships throughout the organisation and into the value chain. An organisation may use the strong bonds developed with employees to reinforce its customer relationships (Mitchell et al., 1997). This makes it important to understand the views of employees throughout the organisation in developing relationships that provide market information.

\section{Method}

Premised upon the strategic contribution of internal stakeholders, the current research examines employee attitudes and behaviours regarding a formal market orientation program. Research was carried out in two stages. The first stage identified an organisation using market-oriented tactics. The second stage researched employee perspectives highlighting the factors that facilitated or impeded the implementation of this strategy.

\section{Context of the Research}

The study was undertaken with a large Canadian-based financial services company. Market orientation is important to the financial services industry because competitive advantage is more likely to come from intangible factors, such as customer relationships that contribute to the firm's unique capabilities (McNaughton et al., 2002). Additionally, the services sector accounts for up to three-quarters of the GDP of developed countries (Gray et al., 2003). Using an aggressive acquisition strategy, the

company became one of the largest insurance companies in Canada, exhibiting superior earnings capabilities, and was highlighted as one of the top 50 workplaces in Canada. The 
company was previously known for its strong connection to distributors. However, this image suffered as the company experienced many strategic and operational changes subsequent to its mergers and acquisitions.

In the financial services industry, distributors play an important part in the consumer buying decision because consumers rely on the distributors' expert advice to make product and company choices. Agent distributors are a rich source of market information about the actions of competitors and the needs of premium-paying and channel customers. Many competitors had increased control over distributors through the employment of "captive" agent distributors. In contrast, the subject company decided to distribute its product solely through independent distributors. As independent distributors were free to sell the products of competitors, it was crucial to maintain strong ties.

Selecting a market-orientation strategy. A year prior to the study, the president of the company decided to re-launch a market-oriented relationship strategy targeted at distributors. Unique in the industry, and viewed by the president as a competitive advantage, the Agency Call Program (ACP) provided a good context for the current research. It was a market-oriented initiative designed to facilitate the exchange of marketbased information through the development of relationships with distributors. This program required selected employees throughout the organisation to make regular phone calls to selected distributors. Following the phone call, employees relayed information via email to senior executives. The strategy was a building block of the company's objectives to stay in touch with customer and distributor needs.

One hour interviews were conducted with twelve executives from various functional areas. Through interviews, an understanding developed of their expectations 
and support for market-oriented behaviours in each functional area, for example in marketing or underwriting. Executives varied in their support of a market-oriented objective for the agency call program, giving mixed messages regarding the tradeoff between the "core" duties and market-oriented duties of agency callers.

Ten distributors across Canada were also interviewed to investigate the level of market orientation of the organisation and the agency call program. Their input established the value of different market-oriented behaviours to channel customers. Agents were asked to provide examples of employee behaviours that provided value, their expectations of executive and other employees. They were also asked to comment about the content and competitiveness of the company's service and products and to give their opinions about the scope of the Agency Call Program.

Investigating the views of employees toward a market-orientation program. Five focus groups (30 management and non-supervisory employees in total) were conducted over a two month period, and were evenly split between company offices in Eastern and Central Canada. Where possible, management was separated from non-management participants to avoid political pressures. Two researchers facilitated the focus groups, directing the discussion and noting intra-group verbal and non-verbal communication. Each two hour session was audiotaped or videotaped and later transcribed. In total, the sessions generated about 150 pages of transcripts. Table 1 profiles focus group demographics.

Participants were chosen with varied levels of participation and commitment to the program, including those actively making calls or not making calls, long-term or short-term, and differing tenure and companies of origin. The gender distribution in each 
group roughly reflected the gender distribution of these positions in the company and the industry as a whole (four women for each man in the employee focus groups). Although many participants were underwriters, others were claims adjusters, customer service representatives, support services representatives, training and development personnel, actuaries, and marketing representatives. They came from all business lines, including individual, group, life insurance, pensions, disabilities, and investment products.

\section{Analysis}

The data were analysed to identify significant issues and stakeholder conceptions of program value. Review of verbal and non-verbal communication patterns in the focus group discussion revealed common themes.

\section{Take in Table 1}

Focus group discussions provided information regarding the views of both middle management and non-supervisory employees. Word context and frequencies were tabulated from the employee focus group data. First the number of observations for a qualifying word was calculated, such as "should" reflecting expectations, "able to" or "can" reflecting ability or self-efficacy, and "relationship". These common frequencies were analysed in proportion to the total words transcribed in the focus groups (Table 1).

As focus groups provide a rich source of verbal and non-verbal interaction between participants, it was important to establish word context. Therefore, in addition to quantitative observations relating word frequencies, more qualitative aspects were considered with respect to group dynamics, length of time spent on a vein of discussion, 
revival of topics upon the entrance of new participants and the level of agreement/disagreement on the topic. Streams of discussion surrounding frequently used words were analysed in order to understand level of agreement and interest levels (length of time spent discussing topic). Issues significant to employees emerged from these streams.

\section{Results}

Results of first stage interviews indicated that executives wished to develop a market-oriented culture, and that the company was generally considered by distributors to be market-oriented in comparison to its competitors. Additionally, their comments supported the Agency Call Program as including many of the elements of a marketoriented program. Employees in the focus group also placed value upon market-oriented aspects of the program. The following section describes this in more detail.

Proscribed Market-oriented Behaviours: The Agency Call Program

Executive Employee Stakeholders. Table 2 includes quotes that highlight the different executive objectives for the program. This demonstrates that the implementation of a market-oriented strategy might be coupled with other strategic objectives and expectations in a real-life business situation. All executives viewed the relationship development between the organisation and the agency, and the agency callers and the agent principals/administrators as critical to success. Most believed that it was necessary in principle for all employees to be market-oriented. However, the marketing executives still believed that marketing was the best equipped to interact directly with agency/distributors, and in this, were seconded by the operational areas not responsible 
for the implementation of this program. This view reinforced the need to control for interfunctional differences when setting a market-oriented strategy. The inter-functional differences also emphasized defensiveness, and the reciprocal distrust of the capabilities and motives between regional marketing and head office operations.

Take in Table 2

Table 3 includes the differences in expectations of employees who were participating in the market orientation program. As these employees (also referred to as "agency callers") were from all areas of the company, the executives responsible for each area were interviewed. The quotes highlight the personal differences in the ways each executive responded to agency call queries and information.

The market-oriented dimensions of information acquisition and dissemination were clearly included in caller behaviours. Callers were expected to obtain information and to share it through the dictated email channels. However, there was less agreement on the type or responsibility for response. Some believed that callers should take ownership of the issue, whereas others believed an issue should be passed on to someone else for resolution. In spite of these differences in specifics, executives, employee callers and distributors unanimously agreed that to have value, the program must include a strategic or administrative response to concerns voiced by distributors.

Take in Table 3 
Distributor Stakeholders. The input of 10 distributors across Canada established the value of different market-oriented behaviours to target "customers", who were in this case, external agents/distributors. When asked how the company compared to its competitors in its market orientation, nine of the ten participants believed that the company was superior to its main competitors at maintaining relationships and open channels of communication with distributors. All interviewees described frustration with the poorly integrated legacy information systems of the company. These systems were important to the effective dissemination of knowledge throughout the company.

Additionally, if agent principals (owners of the agency) did not see value in the relationship, then they responded by asking office administrators to assume responsibility or by refusing to deal with the company. Effective acquisition of external information relied upon the individual employee's ability to reciprocate by giving internal information to the agent.

To summarize, the ACP was introduced by the President to support a strategy of market-orientation, in a market where distributors viewed the organisation as having a market-oriented culture with an emphasis on relationship development. At a high level, executives believed that it was important for employees throughout the company to espouse market-oriented values, but were divided in their support of actual marketoriented behaviours. This indicates that the views of employees on the implementation of the ACP program might increase understanding of other issues that might block or facilitate front-line market-oriented behaviours.

Non-executive Employee Stakeholders. Most participants in the employee focus groups agreed that the agency call program (ACP) had value, particularly in developing 
an open channel of communication between the organisation and its distributors. This acknowledgement of the value inherent in meeting distributor needs supports the existence of a market-oriented culture in this organisation. These views also support an understanding of the market-oriented program objective identified by the President when it was introduced. Despite the value perceived in the program, ACP calls occurred inconsistently or not at all. The participants identified problems related to multiple program objectives, implementation, and ongoing procedures. Underlying issues were a mismatch between program objectives and implementation, inconsistent top management support, and inefficient information flows.

Employee Issues and Value Conception

Each focus group raised issues relating to antecedents of the call program. As primary actors, they initiated the program through their market-oriented actions. Employees examined their market-oriented actions and explained their motives. Issues surrounding time, efficacy (how effective they believed they performed the task), curiosity, and program design were raised in each focus group.

Time. Evident from the word frequencies in each focus group (Table 1), the theme of time flowed through all focus groups: they were concerned that this new strategy was not central to their role, and it was competing for their already stretched resources.

Sample Time Stream

Person 1: We're inundated with our own jobs.

Person 2: I'm challenged to keep up with all the information I have to keep up on 
Person 1: True I'm too busy working on other strategic projects and just day to day put out fires type... to trying to solicit from an advisor or customer on what it is that makes

Person 3: When you try to get answers [from the agents] to high level questions, they say "oh yeah it's fine." They don't have time.

Person 4: The key to the agency call program is making time. They should teach a course on that. They [agent calls] take a lot of time....

Efficacy. Employees frequently described actions in terms of "can" and "able". An emphasis on efficacy and curiosity was also indicated by the frequency and context of the words "know" and "don't know". An efficacy-themed stream of conversation is reflected in the following example:

Person 1: So I think in that way I think that people are comfortable talking about their area of expertise and not outside their areas. Maybe that's what we should be focusing on.

Person 2: I often feel stupid doing my calls, almost everything I've been asked to address them on has been outside my area.

Person 3: ... I can't believe that I'm going to uncover it [an issue of importance] and I'll be the first to hear about it.

Person 4: I was excited that some things were resolved that he brought up with me, but I don't know if I can take credit for that, maybe they just worked out on their own?

In another discussion, this point was made:

I think you need some basic abilities, it's okay not to know the answers and what not, but what you do need is the ability to ask questions, ask enough questions to get a sense of what the issue is then you can pass it along. And I think if we're going to bring those people in to the program we have an obligation to train those people, or they shouldn't be in the program period. You may have someone who works for you who's a real crackerjack worker but if they've never had experience in asking questions and drawing out answers, it's hard to get enough information - that takes practice. 
Curiosity. In addition to efficacy, participants raised other individual reasons for differences between employees who were actively making calls and those who were not. For example, curiosity, personality and status were also discussed. A sample curiosity stream was:

Person 1: I'm interested in whether the people in this room have the same amount of curiosity. If we are asked a question about a product, we don't just pass it on, we find out for ourselves.

Person 2: Explain it to me...

Person 3: How does it work?

Person 2: Even if you don't know the answer you will find it for next time.

Person 4: I agree with you J., we are a nosy lot.

Continuing discussion about curiosity...

Person 4: Most people thrive on it - gain a whole lot of understanding as a whole.

Program Design Issues. Program design issues also emerged in the focus groups. Face-to-face visits with distributors were often suggested as a superior alternative to the market-oriented call program. Relationships versus information appeared to be competing objectives that shaped the way employees conducted their distributor calls. The comments of participants contrasted questions used to develop relationships (more openended, relying on the other party to raise issues) with the "tough" questions that were more specific, probing and market-oriented.

Employees in each focus group noted that they needed more contextual information prior to the first contact so that they understood the agent's status, priorities and relationship with the company. The value of on-site visits and face-to-face communication was also emphasized as creating a more "honest", "brutally frank", and 
"better relationship" than phone calls. The underwriters who dominated this part of the discussion viewed the visits as part of their core duties. The visits occurred regularly so that underwriters could communicate policies and practices to the agencies.

Additional design issues were flagged as the perceived value of the calls decreased over time. More than half of the participants in the focus groups discussed decreasing mutual value, characterized by 1) repeated issues, 2) difficulty in reaching agents, 3) increasing reluctance of agents to spend their time. For example:

It's very discouraging for people who have to call an agency who doesn't want to talk to them. You never ever get ahold of this person, so as far as the ACP is concerned, you're a failure. Your name didn't get a tick next to it.

Program Outcomes. Employees were also concerned with program outcomes. They wondered if other stakeholders valued the program. From a relationship perspective, they had received no assurances that agents viewed it as valuable. These streams consider participants' skepticism about its value to agencies:

Stream 1

Person 1: I have no personal relationship with this man, so I have conversations with him but I don't think he's getting anything out of it and I don't think anyone at the company is getting anything out of it.

Person 2: I wonder if it's [the agency call program] a bit redundant. I can't believe that there is an important issue that hasn't already been brought up with our regional marketing consultant.

Stream 2

Person 3: the other thing is: are the agents getting anything out of it. For me I don't think the agent is getting anything out of it. So are our efforts resulting in them feeling like they have a contact?

Person 4: I think that what they get out of it is that at least we're expressing that we care. That we get enough out of them to find out if they're happy with this or 
that. Maybe that's all they want do they need anything. Sometimes it's just a matter of "gee they picked up the phone and asked, they care". I think that's the gist of the program.

They also debated whether executive strategy makers viewed the program as valuable. Participants who voiced skepticism about the value of the call program to distributors and even to management, did not fully participate in the program. These employees found it difficult to pursue distributors who did not want to talk, even using the word "stalking" to describe their efforts. Others cynically described the value to corporate decision-makers as "window-dressing" and questioned the value of asking agents who had only "lovely" things to say about the company.

Role Conflict. Employees were concerned with how the program fit into their current role with the company. The frequent use of the word "should" indicated that this evaluation was on their minds. They often resented "being volunteered" and believed that the ACP involved extra-role responsibilities. This disgruntlement was exacerbated by the inclusion of the program in their performance accountabilities, but not on the accountabilities of other non-caller employees performing the same role.

\section{Sample Role Conflict Stream:}

Person 1: I would think it's not actively our role to find out what the competition's doing.

Person 2: I think people who deal with the general public and agents, the inquiry people, would have those skills because that's part of what they need everyday anyway. But if you're talking about admin people, those that deal mainly with their coworkers every day, those skills aren't honed as well.

Person 3: But I don't believe in the call program, I don't think it should be used as a tool I don't think admin people should be used for marketing 
Person 4: ...how relevant is this to my job? I mean they made it an accountability for assessing risk. And our reviews are set up in 2 parts, objectives and competencies. But nowhere do I see this program as being relevant to my job. Agency visits I can see, my interaction that customer service of educating agent and advisor. I don't see myself gathering information about the company and solving it as being relevant to my job.

Another area of role conflict concerned the wide range of expected marketoriented behaviours. Conflicting instructions from different executives at different times created inconsistent caller responsibilities. Some employees were open to the information acquisition and sharing aspects of the program, but hesitated over the time needed to coordinate a response. For example:

I have to admit that when we were first called ... I thought it was a good idea. I think it's great to have the communication and reported and all of this to share. But when it changed to being responsible for solving problems, it changed it all to me. But I can't change it. I don't know who it should be reported to-and I can't help.

\section{Discussion}

The objective of this paper was to increase understanding of the multiple roles of internal employee stakeholders, and to identify barriers and facilitators to market orientation. The implication of study findings are discussed in this section.

Understanding the Big and the Small Picture

Participants related concerns about issues that directly impacted their individual stakes in the organisation. Executive strategy-makers expected employees to adopt behaviours that reflect understanding of the larger organisational context. Interestingly, these focus groups also identified a need for executives to develop and implement their strategy with a similar understanding of more specific issues. For example, study results 
highlight the importance of employee attributes. Successful program implementation relied upon employees who were actively engaged in the program, making calls, asking probing questions, relaying the information and helping to solve issues. They discussed the importance of a curious disposition, or learning orientation and of control over both the discussion topic (expertise) and the internal company processes (issue resolution). They exhibited further self-efficacy through a general understanding of the ways in which their own roles contributed to the organisation's overall success.

\section{Aligning Strategy with the Status Quo}

Issues of role conflict and competing demands on employee time reinforce a need to align separate strategies, such as market-oriented programs, with role descriptions and accountabilities already in place. Issues relating to program design and outcomes are related to effective two-way communication channels between executive decision makers and employee stakeholders. A common conception of value linked stakeholders in a value chain. Interaction between the stakeholders does not occur if they do not feel the exchange is of value. Study results indicate that employee stakeholders derived some value from perceiving the value of the program to others. However, the lack of feedback from the other stakeholders detracted from the willingness of the employees to buy into the program's value.

Study results also raise important issues about the implementation of a "formal", or proscribed market orientation strategy. Many participants in the study believed that the new strategy involved duties that were outside of their regular jobs. Strategy-makers expected employees to adopt a market-oriented philosophy, but the behaviours 
themselves could not be singled out and prioritized over core job functions. This suggests that a strategic orientation such as a market orientation must be developed over time.

\section{Understanding Competing Program Objectives}

The differing views of the objectives for the program raises a question of whether the same employee behaviours or the same market orientation program can sufficiently meet both relationship and content goals. Essentially, does a market-oriented strategy compete with a relationship-oriented strategy? Employees believed so and shaped their questions differently. However, in order to get market information from the brokers, employees had to provide something of value in return. This usually involved an exchange of information, as the employee attempted to explain and expedite broker requests throughout the organisation.

The requirement of two-way participation emphasizes understanding of the different perspectives of these stakeholders. If both external distributors and internal employee stakeholders do not see value in the program, they may not be willing to participate. Without equal participation, the market orientation and information exchange process is in jeopardy. It also flags an area that strategy makers should clarify for employees. The questions that employees believed built a relationship were largely open-ended and non-specific. Although this phrasing can be used to start a conversation, a more specific exchange of information needs to take place in order to provide translatable value to both stakeholders' business interests. 


\section{Reciprocity}

This study highlights how a successful market orientation strategy must provide value to all stakeholders and raises an important issue for future research. Previous researchers have tested market orientation as unidirectional information management. This ignores the two-way nature of the communication process - one that must be reciprocal and iterative. It may be insufficient to try to measure information acquisition without also attempting to measure the reciprocated value. Distributors interviewed in this study stressed the importance of program value before they would willingly participate. Even as they recognized that it was important for the organisation to be market-oriented in order to be competitive, the distributors also required tangible and reciprocated value in return for market information. Often the value stemmed from organisational response to their inquiries, the final part of the market orientation construct, and as noted, the most debated by internal stakeholders. This issue of reciprocated value becomes important when considering market orientation in a valuechain relationship because distributors hold both increased responsibility and power as intermediaries.

Participants focused upon the scarcity of time allocated to develop relationships with distributors. Strategy-makers seeking to implement such a market-oriented program must assess the additional time necessary to develop this reciprocal value.

\section{Splitting the Market Orientation Construct}

The focus groups were generally composed of non-marketing employees. Only three participants of the 30 were in a marketing-related field: one was in a head office 
market research area, one in promotions, and one in product development. Therefore, the focus groups were dominated by participants who did not have marketing backgrounds. This mindset may have shaped a general expectation that callers may acquire information, but should not be responsible for developing a strategic response. Implementation of a market orientation is complicated by inter-functional barriers splitting the key dimensions of the construct. It becomes difficult to measure an individual employee's market orientation when the employee is only deemed responsible for acquisition and dissemination, and not for inter-functional coordination of a strategic response. This indicates that even informal market orientation may be discouraged by traditional functional separation of duties.

An understanding of extra-role behaviours can also inform this finding. Extra responsibilities are studied within the framework of organisational citizenship or extrarole behaviours (Organ, 1988) and are responsibilities outside of proscribed job duties. Employees who are satisfied with their jobs and committed to the organisation are more likely to perform extra-role behaviours (MacKenzie et al., 1998). In contrast, if tasks are viewed as expected in-role behaviours, employees are more likely to become more satisfied and committed upon task completion. (MacKenzie et al., 1998). For example, in order to carry out their core job, sales and marketing employees must actively canvass for market information whether they feel satisfied or not. The fulfillment of this job duty will increase their satisfaction. However, employees in areas such as finance or operations who are dissatisified or uncommitted are unlikely to perform discretionary behaviours with regard to market information. 


\section{Contributions}

This research contributes to our knowledge of the internal stakeholders involved in a market-oriented strategy. Shifting the focus from the external target of the process, the focus groups explored the attitudes and behaviours of internal stakeholders. This study expands previous empirical research using strategy-makers by providing insights into the views of internal stakeholders who are responsible for implementing a proscribed market orientation policy. Findings emphasize that continued cooperation between strategy-makers and strategy-implementers must be translated into clear directions with feedback and support.

The issues raised by different groups of employees increase our understanding of their multiple roles and how these roles can facilitate or impede the achievement of market-oriented objectives by a market-oriented company. Differences across employees were identified with respect to organisational role, functional area and individual traits. This finding signals the importance of customizing the program and process to fit with the varying interests of different internal stakeholders.

Most empirical market orientation studies have gathered information from manufacturing companies, and only recently have studies considered the service sector (e.g., Gray et al., 2003; Harris and Piercy, 1999; Kennedy et al., 2002; McNaughton et al., 2002). The increased importance of customer service makes it important for a customer or market orientation to be present at all levels of the organisation. 


\section{Limitations and Implications for Future Research}

This qualitative study design facilitates a deeper understanding of attitudes, but limits the generalisability of the data to other firms. Although collected from a variety of stakeholders, data collection was restricted to views surrounding the launch of a specific market-oriented program and limited to one financial services firm. In order to achieve a deeper understanding of internal stakeholder views, the data was collected using qualitative methodology. Further empirical quantitative research is needed to build generalisability. Quantitative work might examine the types of behaviours practiced by market-oriented individuals.

This qualitative research also provides insights into potential antecedents of market-oriented behaviour, such as curiosity or learning orientation and self-efficacy. The reciprocity involved in the practice of market-oriented behaviours increases the importance of interpersonal issues in the study of these behaviours at the level of an individual. Future researchers must study the impact of relationship-based psychological contracts between employees and their employer, peers, and customers.

\section{Practical Implications}

Information gathering and its dissemination throughout the firm represent organisational capabilities. However, employees must recognize and use these informational capabilities to create sustainable competitive advantage. This is evidenced by the high failure rate in Customer Relationship Management (CRM) systems (Earley, 2002; Tehrani, 2002). Such systems are often implemented to improve market orientation 
by gathering customer information and disseminating it within the firm. This research provides firms with a stronger understanding of the dynamic processes required for a market orientation.

Strategy-makers must clearly define how strategy and behaviours fit into each stakeholder's objectives. A market-oriented strategy consumes an enormous amount of time, as individuals acquire and share information. In order to dedicate enough time to make the program successful, stakeholders must have a clear idea of its value and its fit within their core job duties. The width of the market orientation construct creates practical implementation challenges and may require allocation of market-oriented responsibilities along traditional boundaries between functional responsibilities.

In conclusion, this research adds to the understanding of issues that are important to internal stakeholders. A market-oriented strategy may introduce tactics that involve employees at all levels of the company. This will stimulate a vibrant market orientation but only when the interests of both internal stakeholder partners and external stakeholder targets are realised. 
Table 1

\section{Focus Group Composition and Word Frequencies*}

\begin{tabular}{|c|c|c|c|c|c|}
\hline For All Groups & Group 1 & Group 2 & Group 3 & Group 4 & Group 5 \\
\hline Employee Level & $\begin{array}{l}1 \text { manager } \\
1 \text { supervisor } \\
2 \text { underwriters }\end{array}$ & $\begin{array}{l}4 \text { managers, } 3 \\
\text { supervisors }\end{array}$ & $\begin{array}{l}\text { 3Underwriters, } \\
\text { Mkt research } \\
\text { specialist, } \\
\text { Investment } \\
\text { Products, } \\
\text { Customer } \\
\text { Service Rep, } \\
\text { Training Coord }\end{array}$ & $\begin{array}{l}5 \text { managers } \\
2 \text { supervisors }\end{array}$ & $\begin{array}{l}3 \text { underwriters, } 2 \\
\text { very senior } \\
\text { prof'ls. }\end{array}$ \\
\hline Areas & $\begin{array}{l}\text { National } \\
\text { Accounts }\end{array}$ & $\begin{array}{l}\text { Customer } \\
\text { service, new } \\
\text { business, IP, } \\
\text { administration, }\end{array}$ & $\begin{array}{l}\text { Market research, } \\
\text { underwriting, } \\
\text { HR/Mktg, } \\
\text { customer service }\end{array}$ & $\begin{array}{l}\text { Retail new } \\
\text { business, life } \\
\text { customer } \\
\text { service, cash } \\
\text { mgmt }\end{array}$ & $\begin{array}{l}\text { Underwriting, } \\
\text { actuarial, new } \\
\text { business }\end{array}$ \\
\hline Region & Toronto & Toronto & Halifax & Halifax & Toronto \\
\hline Level & Mixed & Management & $\begin{array}{l}\text { Non- } \\
\text { management }\end{array}$ & Management & $\begin{array}{l}\text { Non- } \\
\text { management }\end{array}$ \\
\hline $\begin{array}{l}\text { Number of } \\
\text { Words }\end{array}$ & 7948 & 9348 & 9142 & 6298 & 4727 \\
\hline $\begin{array}{l}\text { Prioritized } \\
\text { words: }\end{array}$ & $\begin{array}{l}\text { Prioritized } \\
\text { words: }\end{array}$ & $\begin{array}{l}\text { Prioritized } \\
\text { words: }\end{array}$ & $\begin{array}{l}\text { Prioritized } \\
\text { words: }\end{array}$ & $\begin{array}{l}\text { Prioritized } \\
\text { words: }\end{array}$ & $\begin{array}{l}\text { Prioritized } \\
\text { words: }\end{array}$ \\
\hline 1. $\quad$ Call & 1. $\quad$ Call & 1. Call & 1. But & 1. $\quad$ Call & 1. $\quad$ Call \\
\hline 2. $\quad$ But & 2. $\quad$ But & 2. $\quad$ But & 2. $\quad$ Call & 2. $\quad$ Know & 2. $\quad$ But \\
\hline 3. Know & 3. Know & 3. Know & 3. Know & 3. But & 3. Know \\
\hline 4. Time & 4. $\quad$ Time & 4. Can & 4. Time & 4. Info & 4. $\quad$ Time \\
\hline 5. Can & 5. Can & 5. $\quad$ Visit & 5. Can & 5. $\quad$ Time & 5. Info \\
\hline $\begin{array}{ll}6 . & \text { Info } \\
\end{array}$ & 6. Info & 6. $\quad$ Time & 6. Don't know & 6. $\quad$ Can & 6. Can \\
\hline 7. Don't know & 7. Don't know & 7. Info & 7. Info & 7. Able & 7. Job \\
\hline $\begin{array}{ll}8 . & \text { Visit }\end{array}$ & $\begin{array}{ll}8 . & \begin{array}{l}\text { Relation- } \\
\text { ship }\end{array} \\
\end{array}$ & $\begin{array}{ll}\text { 8. } & \begin{array}{l}\text { Relation- } \\
\text { ship }\end{array} \\
\end{array}$ & 8. $\quad$ Able & 8. $\quad$ Should & 8. Don't know \\
\hline 9. $\quad$ Should & 9. $\quad$ Visit & 9. Customer & & 9. Admin & Should \\
\hline \multirow[t]{6}{*}{$\begin{array}{l}\text { 10. } \begin{array}{l}\text { Relation- } \\
\text { ship }\end{array} \\
\end{array}$} & 10. Customer & 10. Value & & 10. Too & \\
\hline & 11. Should & 11. Don't know & & 11. Visit & \\
\hline & 12. Same & 12. Should & & & \\
\hline & 13. Too & 13. Admin & & & \\
\hline & & 14. Principal & & & \\
\hline & & 15. Too & & & \\
\hline
\end{tabular}

$*$ constituting more than $.2 \%$ of the total dialogue 


\section{Table 2}

\section{Executive Views of Agency Call Program (ACP) Objectives and Value}

\begin{tabular}{|c|c|}
\hline Executive Area & Program Objective and Value (Quotes from Executive Interviews) \\
\hline $\begin{array}{l}\text { Sales and Marketing } \\
\text { Ontario }\end{array}$ & $\begin{array}{l}\text { - To introduce consistent treatment and understanding of customer/distributor across } \\
\text { company. Useful, only if it doesn't take time away from core responsibilities }\end{array}$ \\
\hline $\begin{array}{l}\text { National Accounts } \\
\text { Ontario }\end{array}$ & $\begin{array}{l}\text { - A conduit for a problem: "now that I have you on the line, can you solve this?" We } \\
\text { fix that for you - that's great - good. It's redundant because the structure is there to do } \\
\text { it. But I don't think there's any thought about what the end result should be. }\end{array}$ \\
\hline $\begin{array}{l}\text { Marketing Strategy, } \\
\text { Head Office }\end{array}$ & - $\quad$ Provide continuity with agency through caller \\
\hline $\begin{array}{l}\text { Sales and Marketing } \\
\text { Ontario }\end{array}$ & - To create consistent customer understanding across company \\
\hline $\begin{array}{l}\text { Sales and Marketing } \\
\text { Western Canada }\end{array}$ & $\begin{array}{l}\text { - Increase employees' versatility and confidence, knowledge of other jobs and } \\
\text { functions, increase knowledge of the challenges of the marketplace } \\
\text { - Program builds relationships with brokers and gives opportunity to get unbiased } \\
\text { feedback without filtering. }\end{array}$ \\
\hline $\begin{array}{l}\text { Sales and Marketing, } \\
\text { Eastern Canada }\end{array}$ & $\begin{array}{l}\text { - What call program does, gives a "warm fuzzy" - We are the only company to take the } \\
\text { time to make calls - shows we care } \\
\text { - Centers around administration issues rather than sales issues } \\
\text { How is the level of service to agency as opposed to how our product stacks up against } \\
\text { the competition. So, it can't deal with competition. Marketing can deal with } \\
\text { competition and we do a good job. }\end{array}$ \\
\hline $\begin{array}{l}\text { Sales and Marketing } \\
\text { (Quebec) }\end{array}$ & - Tries to ensure that all employees have access to market information \\
\hline $\begin{array}{l}\text { Operations } \\
\text { Administration (Head } \\
\text { Office B) }\end{array}$ & $\begin{array}{l}\text { - Helpful to give us an advance warning of something that is going wrong systemically. } \\
\text { - Use the program to appeal to their egos [distributors] by allowing them to talk to } \\
\text { people they don't usually get a chance to talk to. } \\
\text { Important that the people in the companies making the decisions are contacting } \\
\text { distributors on a regular basis. }\end{array}$ \\
\hline $\begin{array}{l}\text { Retail Pricing and } \\
\text { Design (Head Office } \\
\text { B) }\end{array}$ & $\begin{array}{l}\text { - Goal of the program is to create familiarity and ease of doing business with between } \\
\text { our company and our advisor partners, so the familiarity is by having someone who } \\
\text { you talk to regularly, who you have a bit of a relationship with } \\
\text { - A flag more than anything, and a pipeline. I've used it to identify product concerns. }\end{array}$ \\
\hline $\begin{array}{l}\text { Operations (Head } \\
\text { Office A) }\end{array}$ & $\begin{array}{l}\text { Ensures that we stay close to the agencies that are important. The agents have } \\
\text { someone to approach with questions outside the formal loop. }\end{array}$ \\
\hline $\begin{array}{l}\text { Operations (Head } \\
\text { Office B) }\end{array}$ & - Helps develop employees. \\
\hline
\end{tabular}


Table 3

\section{Executive Expectations of Market-oriented Behaviours}

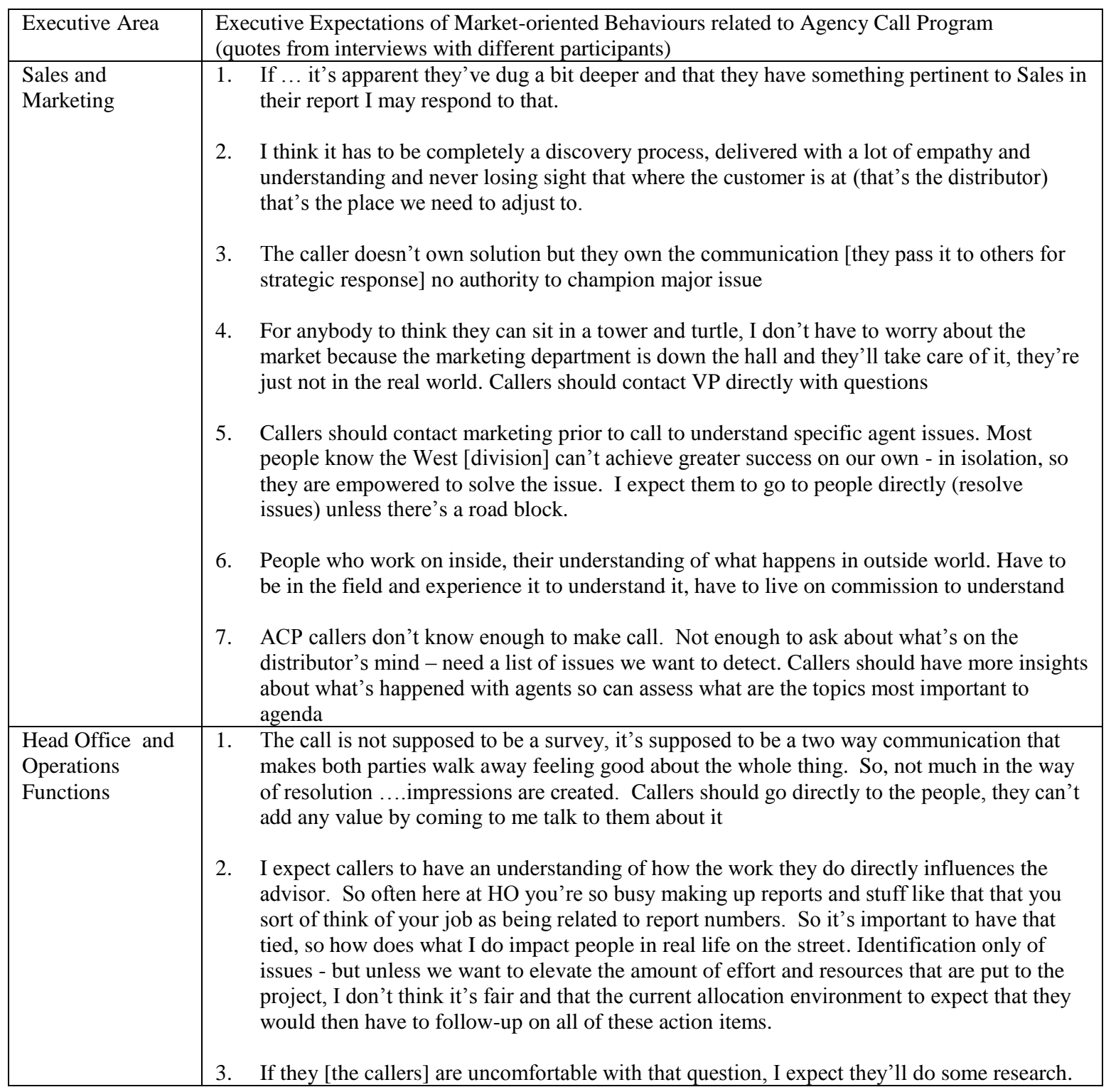




\section{References}

Atuahene-Gima, K. (1996) Market orientation and innovation. Journal of Business Research, 35(2), 93-103.

Celuch, K.G., Kasouf, C.J., and Strieter, J.C. (2000) The influence of organizational market orientation on individual-level market-oriented cognitions. Psychology and Marketing, 17( 11), 935 - 954.

Croteau, A.-M., and Li, P. (2003) Critical success factors of CRM technological initiatives. Canadian Journal of Administrative Sciences, 20(1), 21-34.

Day, G.S. (1994) The capabilities of market-driven organizations. Journal of Marketing, 58(4), 37-53.

Day, G.S., and Wensley, R. (1988) Assessing advantage: A framework for diagnosing competitive superiority. Journal of Marketing, 52(April), 1-20.

Deshpande, R., Farley, J.U., and Jr, F.E.W. (1993) Corporate culture, customer orientation and innovativeness in Japanese firms: a quadrad analysis. Journal of Marketing, 57(January), 23-37.

Dobni, C.B., and Luffman, G. (2000) Implementing a marketing strategy through a market orientation. Journal of Marketing Management, 16, 895-916.

Earley, R. (2002) How to avoid the CRM graveyard. Customer Inter@ction Solutions, 20(12), 26-30.

Eisenhardt, K.M., and Martin, J.A. (2000) Dynamic capabilities: What are they? Strategic Management Journal, 21(10-11), 1105-1121.

Farrell, M.A. (2000) Developing a market-oriented learning organisation. Australian Journal of Management, 25(2), 201-222.

Foa, U., and Foa, E. (1974) Societal Structures of the Mind. Springfield, IL:Charles C Thomas.

Freeman, R.E. (1984) Strategic Management: A Stakeholder Approach. Boston:Pitman Publishing Inc.

Frooman, J. (1999) Stakeholder influence strategies. Academy of Management Review, 24(2), 191-205.

Gray, B.J., Buchanan, T., and Mallon, M. (2003) Linking HRM and Marketing to Improve Service Competitiveness. 2003 World Marketing Congress. 
Greenley, G.E. (1995) Market orientation and company performance: empirical evidence from U.K. companies. British Journal of Management, 6, 1-13.

Greenley, G.E., and Foxall, G.R. (1998) External moderation of association among stakeholder orientations and company performance. International Journal of Research in Marketing, 15, 51-69.

Han, J.K., Kim, N., and Srivastava, R.K. (1998) Market orientation and organizational performance: Is innovation a missing link? Journal of Marketing, 62(4), 30-45.

Harris, L.C. (2002) Sabotaging market-oriented culture change: An exploration of resistance justification and approaches. Journal of Marketing Theory and Practice, 10(3).

Harris, L.C., and Ogbonna, E. (2001) Strategic human resource management, market orientation, and organizational performance. Journal of Business Research, 51(2), 157166.

Harris, L.C., and Piercy, N.F. (1999) Management behavior and barriers to market orientation in retailing companies. Journal of Services Marketing, 13(2), 113-131.

Homburg, C., and Pflesser, C. (2000) A multiple-layer model of market-oriented organizational culture: Measurement issues and performance outcomes. Journal of Marketing Research, 37(4), 449-462.

Hurley, R.F. (2002) Putting people back into organizational learning. The Journal of Business and Industrial Marketing, 17(4), 270-281.

Jaworski, B.J., and Kohli, A.K. (1993) Market orientation: Antecedents and consequences. Journal of Marketing, 57(3), 53-71.

Kennedy, K.N., Lassk, F.G., and Goolsby, J.R. (2002) Customer mind-set of employees throughout the organiztaion. Journal of the Academy of Marketing Science, 30(2), 159171.

Kohli, A., Jaworski, B., and Kumar, A. (1993) MARKOR: A measure of market orientation. Journal of Marketing Research, 30, 467-477.

Kohli, A.K., and Jaworski, B.J. (1990) A market orientation: The construct, research propositions. Journal of Marketing, 54(2), 1-18.

Kotler, P., and Armstrong, G. (1996) Principles of Marketing. New Jersey:Prentice Hall.

Langerak, F. (2001) Effects of market orientation on the behaviors of salespersons and purchasers, channel relationships, and performance of manufacturers. International Journal of Research in Marketing, 18(3). 
Leonard-Barton, D. (1992) Core capabilities and core rigidities: A paradox in managing new product development. Strategic Management Journal, 13(special issue), 111-126.

MacKenzie, S.B., Podsakoff, P.M., and Ahearne, M. (1998) Some possible antecedents and consequences of in-role and extra-role salesperson performance. Journal of Marketing, 62(3), 87-98.

McNaughton, R.B., Osborne, P., and Imrie, B.C. (2002) Market oriented value creation in service firms. European Journal of Marketing, 36(9/10), 990-1002.

Mitchell, R.K., Agle, B.R., and Wood, D.J. (1997) Toward a theory of stakeholder identification and salience: Defining the principle of who and what really counts. Academy of Management Review, 22, 853-886.

Narver, J.C., and Slater, S.F. (1990) The Effect of a Market Orientation on Business Profitability. Journal of Marketing, 54(4), 20-36.

Noble, C.H., and Mokwa, M.P. (1999) Implementing marketing strategies: Developing and testing a managerial theory. Journal of Marketing, 63(4), 57-73.

Organ, D.W. (1988) Organizational Citizenship Behaviour: The Good Soldier Syndrome. Lexington, MA:Lexington Books.

Piercy, N.F., Harris, L.C., and Lane, N. (2002) Market orientation and retail operatives' expectations. Journal of Business Research, 55(4), 261-273.

Roloff, M.E., and Campion, D.E. (1985) Conversational profit-seeking: interaction as social exchange. In R.L. Street, and J.N. Cappella, Eds. Sequence and Pattern in Communicative Behaviour. London:Edward Arnold.

Slater, S.F., and Narver, J.C. (1994) Does competitive environment moderate the market orientation-performance relationship? Journal of Marketing, 58(1), 46-56.

Teece, D.J., Pisano, G., and Shuen, A. (1997) Dynamic capabilities and strategic management. Strategic Management Journal, 18(7), 509-533.

Tehrani, N. (2002) Publisher's Outlook: The essence of CRM success. Customer Inter@ction Solutions, 21(1), 2-6.

Uncles, M. (2000) Market orientation. Australian Journal of Management, 25(2), 1-9.

Winter, S.G. (2000) The satisficing principle in capability learning. Strategic Management Journal, 21(10-11), 981-996. 


\section{Biographical Details}

Dr. Francine Schlosser is an Assistant Professor of Management at the Odette School of Business, at the University of Windsor, Canada. Her research focuses upon the influence of the individual employee upon the development and implementation of a firm's strategic orientation. Dr. Rod McNaughton holds the Eyton Chair of Entrepreneurship in Management Sciences at the University of Waterloo, Canada. He is the Director of the Institute for Innovation and Co-director of the Centre for Business, Entrepreneurship and Technology at the University of Waterloo. 